\title{
Classification of Sustainable Business Models: a Literature Review and a Map of Their Impact on the Sustainable Development Goals
}

\section{Eleonora Boffa}

The Royal Institute of Technology Faculty of Production Engineering

Stockholm

Sweden

Antonio Maffei

Associate Professor

The Royal Institute of Technology Faculty of Production Engineering Stockholm Sweden

Sustainable Business Models (SBM) have been seen as a suitable vehicle for organizations to convey sustainability. The SBM requires a company's business strategy to be shaped around sustainability goals. These goals can be integrated into the business strategy by creating an internal commitment focused on sustainability. Enablers play a crucial role in this integration process.

The 2030 Agenda issued by the United Nations set clear goals on sustainable development, i.e. the Sustainable Development Goals (SDGs). Firms are encouraged to design SBM to fulfil these goals. Yet, an extensive investigation of the effect of the SBM applications on the SDGs is lacking.

This paper is based on a semantic analysis of the relevant literature. The results show the internal enablers that support the integration process of sustainability into the organization's strategy. In addition to that, the underlying classification process highlights the clusters of applications for the SBM. These are, in turn, mapped over the SDGs to show the impact of each cluster on each SDG.

Keywords: Sustainable Business Models, Sustainable Development Goals, Application cluster, Internal enablers, Latent Dirichlet Allocation

\section{INTRODUCTION}

Industry 4.0 (I4.0) conveys technological advancements in the manufacturing domain, improving production and operational efficiency and effectiveness [1]. In doing so, I4.0 integrates several new digital (or I4.0) technologies [2] such as Internet of Things (IoT), Cloud Computing, Big Data (BD) and Analytics [3].

Nevertheless, the implementation of these new I4.0 technologies will lead to a real industrial revolution if sustainable development principles are applied simultaneously.

In this view, scholars have discussed the role of digital technologies in sustainable development. Khan et al. in [4] and Tirabeni et al. in [5] argued that these technologies could foster sustainability. Several applications have been identified to use them to pursue sustainability goals [4]. For instance:

- Sustainable smart factories (e.g., IoT and BD analytics as an aid to improve energy efficiency in companies' buildings [6])

- Smart and sustainable cities (e.g., IoT application for smart mobility and transport [7])

- Implementation and adoption of circular economy (e.g., IoT are implemented to track, monitor, control, optimize product utilization and formulate circular strategies [8]); BD analytics supports the assessment of the potential value embedded

Received: January 2021, Accepted: July 2021

Correspondence to: Eleonora Boffa, The Royal Institute of Technology, Faculty of Production Engineering,

Stockholm, Sweden

E-mail: boffa@kth.se

doi:10.5937/fme2104784B

(C) Faculty of Mechanical Engineering, Belgrade. All rights reserved secondary materials [9]).

In view of the above, this paper will focus on the sustainable development aspects instead of the technological advancements.

The industry has tried to enact dedicated management and business to establish an entrepreneurial culture that addresses sustainability at the organization level [10]. Therefore, enterprises are focusing on enhancing their sustainability performances. This has become fundamental to positively contribute to global sustainable development [11,12].

In 2015, the United Nation (UN) had issued the 2030 Agenda for sustainable development that proposes a set of Sustainable Development Goals (SDGs) on the area of critical importance for the planet. The private and government sectors have experienced internal organizational challenges attempting to fulfill the SDGs' targets. The overall market competition has also been affected to the extent that traditional Business models (BM) are no longer profitable [13]. Firms are encouraged to develop a Sustainable BM (SBM) to meet sustainability goals [14,15]. The SBM will define sustainable value creation mechanisms while ensuring profitability $[14,16]$. The SBM requires companies to make sustainability the center of their business strategy [17]. According to [18] sustainability is integrated into the organization's business strategy by creating an internal commitment to sustainability. Enablers will act as premises in the process of integrating sustainability into the company strategy [18].

The contribution of this paper is twofold.

On the one hand, this work identifies the internal enablers that create an internal commitment to sustainability and the most common SBM application 
clusters. The methodology used for this purpose is based on a semantic analysis of the literature which contributes to the originality of this work.

On the other hand, from the state-of-the-art emerge that firms are encouraged to develop a SBM to meet sustainability goals. However, research studies on SBM poorly investigate the SBM applications' effect on the SDGs. Therefore, this paper contributes to the extant literature by presenting a map that show the impact of each SBM application cluster on each SDG.

\section{BACKGROUND}

The concept of sustainability is, to date, poorly investigated through a BM lens: empirical studies and relevant theories are rare to be found in the literature [19]. The scientific and practitioner discussion has recently started to highlight the concept of SBM, although a homogeneous consensus on a common conceptual definition of SBM is lacking [16].

A sustainable value proposition is the primary source of a company's competitive advantage when implementing a SBM [16]. Normally, firms design their value propositions as composed of products and/or services pursuing an economic return. In SBM the value propositions must allow for social and environmental benefits creation. This means that both the company and the public will benefit from the value created [14,19]. The focal company's stakeholder groups are extended to include the environment and society [17], becoming primary stakeholders [20]. The value capture mechanisms must guarantee that the firm and the entire stakeholder groups will benefit from the value delivered [16]. Evans et al in [20] elaborated this challenge suggesting the design of "sustainable value flows" to engage all stakeholders. Environment and society demand will then be aligned with enterprises' internal agenda.

Boons et al. work [14] reviewed the SBM state-ofthe-art to identify the domain's primary research interests. Organizational, technological and social innovation are the three most essential streams identified. In details:

1. Organisational innovation: pursuing sustainable development in an organization means that structural and cultural aspects may need to be changed. The function of the SBM will be to coordinate these attributes accordingly.

2. Technological innovation: a company can reach new markets by designing a SBM that commercialise innovative clean technologies

3. Social innovation: SBM supports social innovation enabling firms to create, deliver and capture social value [14]. Existing markets will be broadened with social purpose innovations (e.g. innovations in consumer offering, changing consumer behaviour [15]).

The 2030 Agenda for Sustainable Development proposed by the UN in 2015 aims to raise awareness of sustainable development challenges and define an action plan to overcome them. The Agenda identifies seventeen SDGs that convey the challenges of society and the planet. The SDGs proposed can only be met with a combined effort from the main actors, companies and society [13]. In this regard, the business sector has a key role in changing its production patterns towards more sustainable ones and at the same time incentivise the customer to prefer sustainable consumption paradigms. Climate change, the need of emerging societies and consequent governmental regulations encourage firms to develop a SBM. However, research studies on SBM poorly explore SBM applications' effect on the SDGs.

According to [14], sustainability goals should be integrated into a SBM to outline new value creation, delivery and capture mechanisms. In particular, the sustainability goals are required to be part of the company's business strategy [17] to implement SBM successfully. Sustainability can be integrated into the business strategy by creating a commitment to sustainability within company's boundaries. The commitment to sustainability further contributes to developing structural and cultural capabilities that trigger sustainability at firm-level [17]. Enablers have to be considered as premises in the process of integrating sustainability into company strategy [18].

Therefore, expanding the organizational agenda to address sustainability issues is triggered by an internal commitment to sustainability. The internal commitment creates a solid baseline for a successful SBM application, and its potential impacts on the SDGs.

The contribution of this paper is twofold. On the one hand, this study proposes the internal enablers that facilitate the integration process of sustainability into the company strategy and therefore create an internal commitment to sustainability. On the other hand, research studies on SBM poorly explore SBM applications' effect on the SDGs. This paper aims at filling this gap by mapping the impacts that SBM applications could have on the SDGs.

\section{METHODOLOGY}

The method used to highlight the internal enablers and the most common application clusters for the SBM is a systematic literature review, based on semantic analysis. The published articles to be analysed are extracted from Web of Science, a science technology and social sciences database, using the keywords "business model" and "sustainability". Filters are applied to only include document type "articles" and proceedings", until 2019. The result of the search produces a final dataset of 1657 papers.

Due to the large dimensions of the dataset, the authors choose to apply a topic modelling technique. Topic modelling is an automatic mapping exploiting machine learning algorithms to extract the latent topics from a text collection. This work uses Latent Dirichlet Allocation (LDA), the simplest and most popular among statistical topic models. LDA estimates the words in the text that are likely for a topic and topics that are likely for a particular paper, using a fixed number of topics $(\mathrm{k})$ decided a priori.

The decision on the optimal value of $\mathrm{k}$ builds upon assessing the following metrics: perplexity and topiccoherence. The perplexity index assesses whether a statistical model fits well the dataset: the better is the 
estimation, the better the model and the lower the perplexity $[21,22]$. The perplexity calculation is performed using a $\mathrm{k}$ interval defined $a$ priori $[23]$. The result is a graph that shows the metric's value for each $\mathrm{k}$ and plots the trend line of the metric. The k-interval is restricted in correspondence with the trend line's elbow. The restricted $\mathrm{k}$ interval will guarantee a low perplexity and exploitable numbers of topics to analyse the topics.

Nevertheless, the perplexity measure does not inspect the semantic. A topic-coherence metric is calculated over the restricted interval of $\mathrm{k}$. The metric checks within each topic if the included words are semantically related based on "co-document frequency of words" [24]. The higher the score, the higher the coherence and the topic interpretability.

The optimal k chose to run LDA corresponds to the higher coherence score value.

Using the resulting optimal value of $\mathrm{k}$ LDA was run using the papers' abstract as dataset. The authors chose the software R to run the scripts, which are based on the study published by Network Analysis Interface for Literature Studies (NAILS project) [25] and by [26]. The result was an intertopic distance map that displays the $\mathrm{k}$ topics as circles and the related list of the most salient terms.

The authors conducted a discretional analysis of the intertopic distance map and the list of the most salient terms, aiming at inferring latent themes in the $\mathrm{k}$ topics. The label and description of each topic were specified based on the theme revealed. The $\mathrm{k}$ topics were further classified depending on their semantic value, i.e. internal enablers, clusters of applications for the SBM and not relevant for the paper's scope.

As a next step, the $\mathrm{k}$ topics identified as a cluster of application were classified based on the SBM research streams outlined in the literature, i.e. organizational, technological and social innovation [14]. This has been the basis for mapping the impact of each cluster of application on the SDGs. The impacts were evaluated and assigned as a result of brainstorming sessions, which took place over two days and involved the team's authors and four researchers.

\section{RESULTS}

Paragraph 3 presented the topic model's perplexity and topic-coherence as the metrics to be assessed to determine the optimal value of $\mathrm{k}$.

Figure 1 displays the perplexity index graph plotted over the number of topics. The trend line (in blue) bends between k 15 and 25 (highlighted in red). Therefore, this $\mathrm{k}$ interval is used for the computation of the topiccoherence index.

Figure 2 shows the graph of the topic-coherence score for each $\mathrm{k}$ of the $\mathrm{k}$ interval. The point of maximum corresponds to $\mathrm{k}$ equal 21 , which means the model with 21 topics has the highest topics interpretability. Therefore, the optimal $\mathrm{k}$ is identified, and LDA can be run using 21 as the number of topics.

Figure 3 (see page 5) displays a graphic representation of the result of LDA. The intertopic distance map (a) shows the 21 topics as circles in a twodimensional space on the top part of the figure.

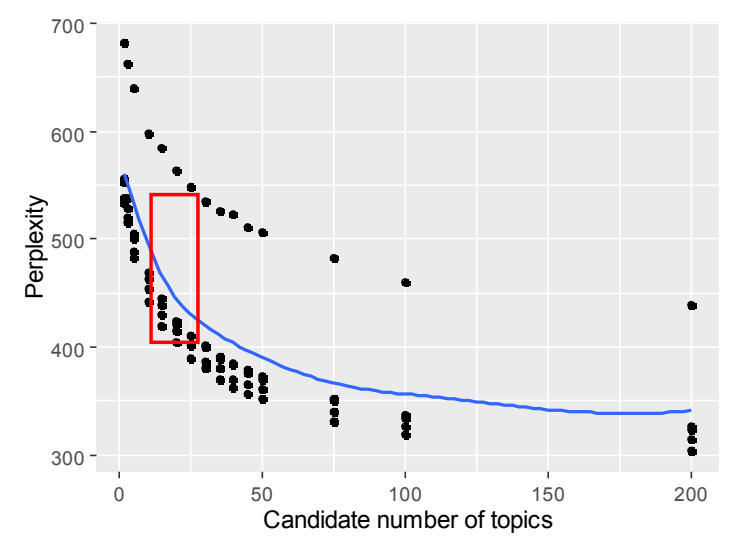

Figure 1. Perplexity index graph. The trend line is in blue. Acceptable k-interval is highlighted in red, where the trend line bends.

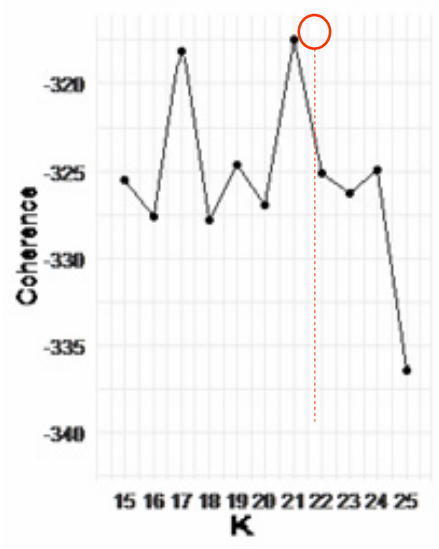

Figure 2. Topic-coherence index graph. Highlighted in red is the value of $k=21$ that has the highest coherence.

The distance among the circles is evidence of semantic connection among the topic: the higher the similarity, the closer the circles. On the bottom part of the figure, the 30 most salient terms (b) are represented with a bar chart. The intertopic distance map and the bar chart are dynamic objects that interact with each other. Selecting one particular circle in the map means that the bar chart will display the most frequent words for that specific topic. The bar value is the estimated term frequency within the selected topic (relevance) [27]. If none of the circles is selected, the bar chart shows the list of the most salient terms in the entire text collection. Accordingly, the bar value is the overall term frequency (saliency) [28].

Therefore, the graphic interface in figure 3 facilitates the assessment of the 21 topics. Each topic's central theme is inferred by reviewing the most frequent words shown in the bar chart for each topic selected (Appendix 1). Furthermore, the 21 topics are classified in five internal enablers, ten clusters of SBM applications and six not relevant for this paper's scope.

\subsection{SBM internal enablers}

Table 1 (see following page) presents the topics that are classified as internal enablers.

Corporate Social Responsibility (CSR) is addressed in topic 10. CSR policies are adopted to renew a company's image showing effort on social and environ-mental issues. 
Topic 4 depicts the Sustainability management enabler. The company's top management plays a central role in addressing sustainability issues. Frameworks should be developed to support the decision-making process regarding sustainability matters.

The sustainable culture is the theme addressed in topic 12 . A shift in the company culture is necessary to support sustainability strategies. New cultural mechanisms should be incentivized to align structure and routines to sustainable development.

Therefore, sustainable development brings cultural changes in the organization and BM innovations, as addressed in topic 8. The SBM innovation enabler indicates that sustainable development could trigger a $\mathrm{BM}$ innovation. In particular, designing Sustainabilityoriented BM (topic 5) enables sustainability strategies to be included in the BM.

\subsection{SBM clusters of applications}

Table 2 presents the application clusters classified according to the three SBM research streams identified in the literature, i.e. organisational, social and technological innovation.

The common clusters of application identified as organisational innovation are Construction projects and Sharing economy.

Topic 11 describes the Construction projects cluster. The cluster's theme reveals that constructions' projects goals must integrate all three sustainability dimensions (i.e. economy, environment and society). Consequently, socio-environment goals will be pursued, creating sustainable value. New BMs need to be designed to capture such value.

The Sharing economy (topic 19) highlights the concept of collaborative platforms that allow collaboration among partners. The Social entrepreneurship, the Fashion industry and the Sustainable production are clusters of SBM applications classified as social innovation.

The Social entrepreneurship (topic 15) has as target group human, animal, plant and abiotic. This leads to building a company's vision and mission on social

objectives. The value propositions will then be created to offer social value to the market. The company's BM must be designed to capture such social value: the BM should translate the social impact into financial success.

The Fashion industry (topic 18) cluster is based on redirecting the traditional "fast fashion" to a "slow fashion" pattern. The aim is to change customer behaviour towards sustainable product consumption.

The Servitization (topic 9) cluster proposes to change the value propositions from offering product ownership to functionality, hence services.

The cluster of Sustainable production (topic 13) highlights the circular economy concept. This new paradigm suggests a circular view of the product life cycle: production applications should be focused on creating new value from waste. The circular economy concept is entirely empowered when innovating the business logic. Therefore, new BMs should be designed accordingly.
Technological innovation has been assigned the following clusters of applications: Renewable energy industry, Digitalization, Urban mobility, Health care system.

Topic 17 depicts the Renewable energy industry cluster. The cluster's theme addresses that technologies are fundamental enablers to exploit renewable energy.

Regarding topic 14, technological advancements have driven the Digitalization within the manufacturing domain. New BMs can guarantee a fit between technology features and their commercialization.

The Urban mobility cluster (topic 16) concerns smart cities' emerging concept. In particular, transportation services should be designed to support more sustainable urban transport development.

Information technology is the core resource for the Health care system (topic 7) cluster to develop new patient services.

Table 1. Internal enablers for SBM

\begin{tabular}{|l|l|}
\hline \multicolumn{1}{|c|}{ Topic label } & \multicolumn{1}{c|}{ Topic description } \\
\hline $\begin{array}{l}\text { Corporate social } \\
\text { responsibility }\end{array}$ & $\begin{array}{l}\text { CSR and corporate } \\
\text { integrated reporting. }\end{array}$ \\
\hline Sustainability management & $\begin{array}{l}\text { Development of } \\
\text { frameworks to support the } \\
\text { decision-making process } \\
\text { within sustainability } \\
\text { matter. }\end{array}$ \\
\hline Sustainability culture & $\begin{array}{l}\text { Cultural changes in } \\
\text { organisations for } \\
\text { implementing a } \\
\text { sustainability strategy. }\end{array}$ \\
\hline Sustainability-oriented BM & $\begin{array}{l}\text { Sustainability to be } \\
\text { included in BM. } \\
\text { Company's strategy should } \\
\text { address sustainability. }\end{array}$ \\
\hline Sustainable BM innovation & $\begin{array}{l}\text { BM innovation for } \\
\text { sustainable development. }\end{array}$ \\
\hline
\end{tabular}

Table 2. The SBM most common clusters of application classified according the SBM research streams

\begin{tabular}{|l|l|}
\hline \multicolumn{1}{|c|}{ SBM research stream } & \multicolumn{1}{|c|}{$\begin{array}{c}\text { Common Clusters of } \\
\text { application }\end{array}$} \\
\hline \multirow{4}{*}{ Organizational innovation } & Construction projects \\
\cline { 2 - 2 } Social innovation & Sharing economy \\
\hline \multirow{4}{*}{ Technological innovation } & Social Entrepreneurship \\
\cline { 2 - 2 } & Servitization \\
\cline { 2 - 2 } & Fashion industry \\
\hline & Sustainable production \\
\cline { 2 - 2 } & Renewable energy industry \\
\cline { 2 - 2 } & Digitalization \\
\cline { 2 - 2 } & Urban mobility \\
\cline { 2 - 2 } & Health care service \\
\hline
\end{tabular}

\subsection{Impact of the SBM cluster of applications on the SDGs}

This section presents how each SBM cluster of application affect the SDGs (see Appendix 2 for description). 
Intertopic Distance Map (via multidimensional scaling)

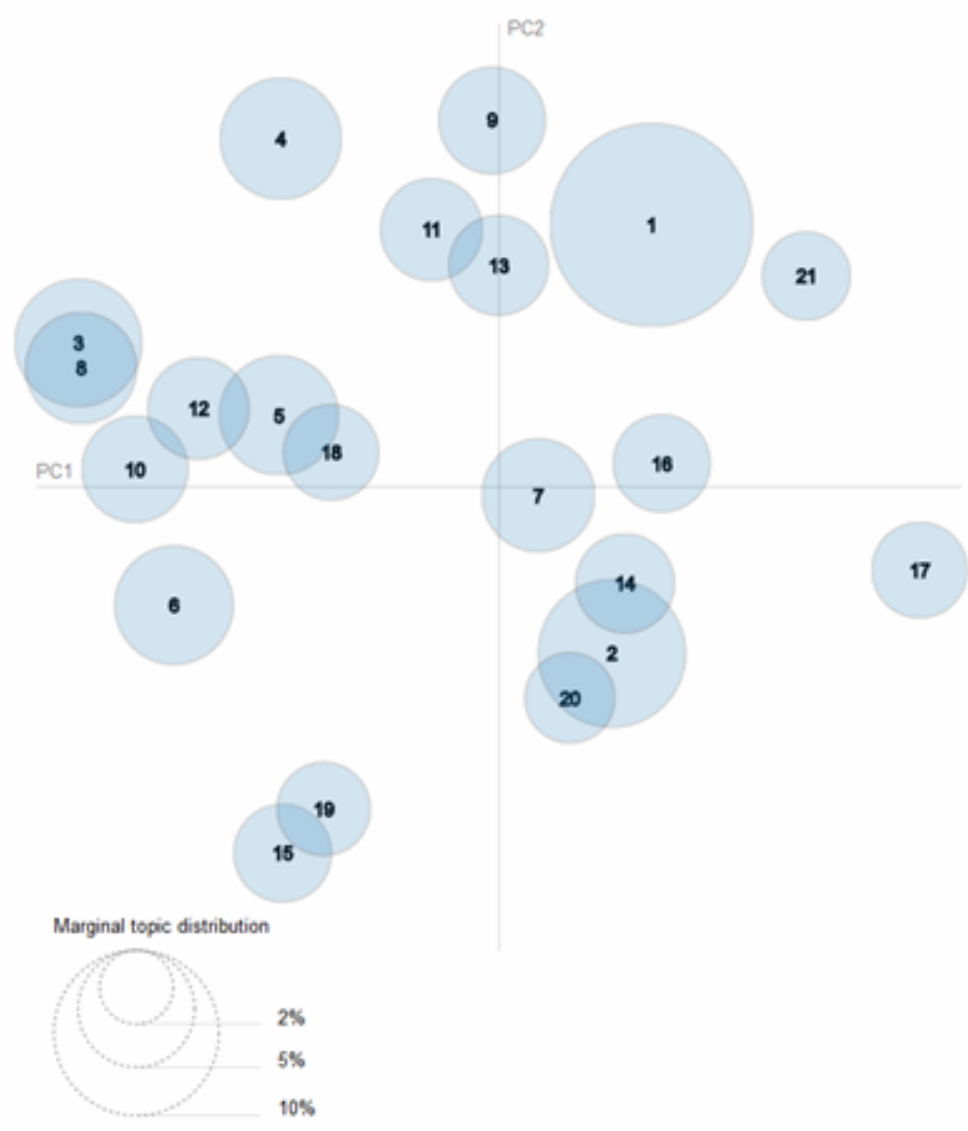

Top-30 Most Salient Terms1

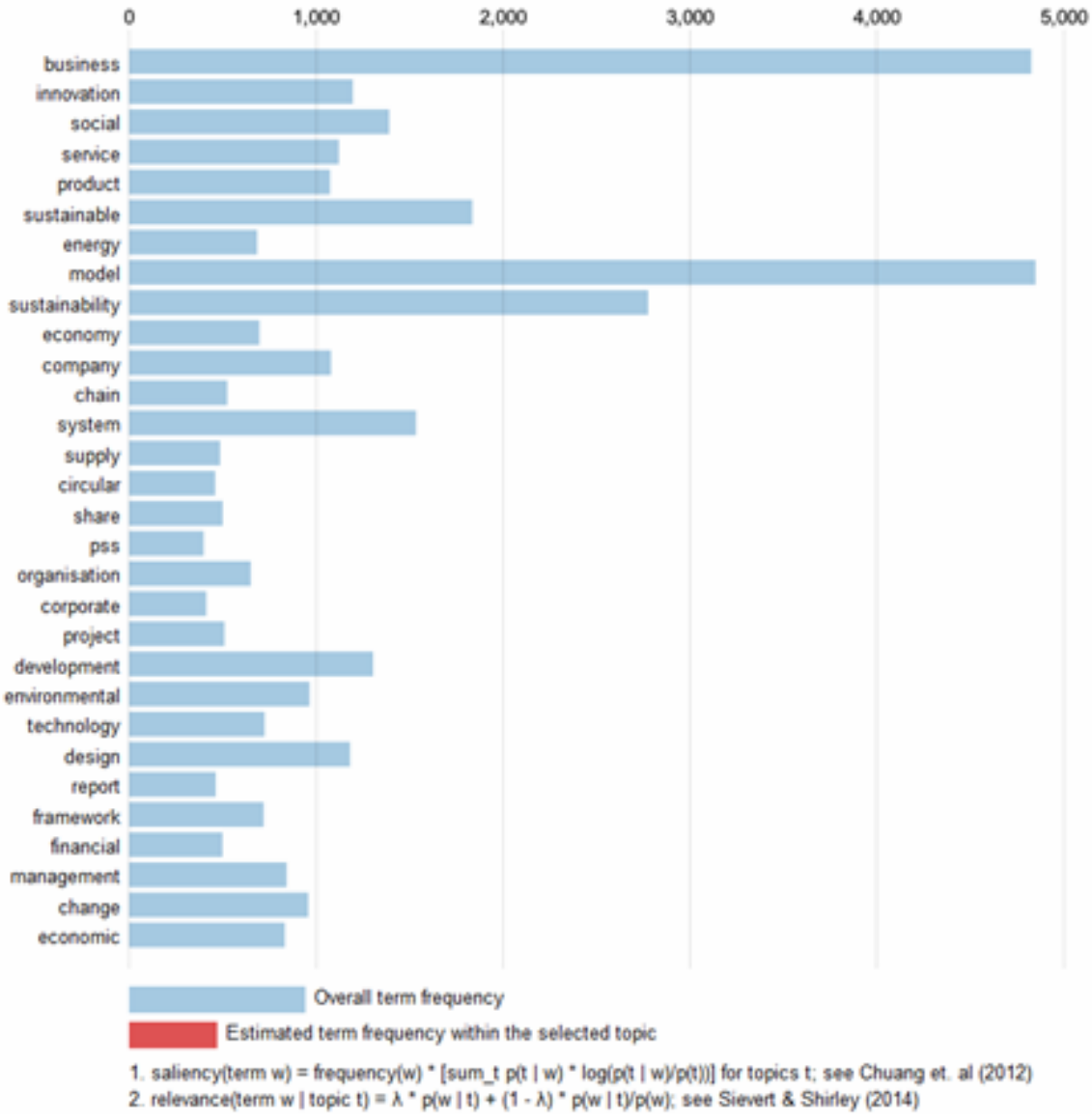

Figure 3. Intertopic distance map (a) and the list of Top-30 most salient terms (b) for SBM literature. 
Figure 4 shows the effect of the Social Entrepreneurship cluster of application on the SDGs.

In details:

- No poverty (SDG 1). Social entrepreneurship initiatives could focus on zero poverty goals in certain areas.

- Zero Hunger (SDG 2). The social value may be created by initiatives to ensure access to nutrition and sufficient food. Resources may be allocated to introduce innovative solutions to enhance agriculture practices and productivity.

- Quality education (SDG 4). Education is the enabler for upward socioeconomic mobility. Therefore, education is fundamental for individuals to escape poverty. Social entrepreneurship would pursue initiatives that incentivise quality education.

- Gender equality (SDG 5). The impact on SDG 5 is triggered by actions taken to fulfill SDG 4 . Education helps reduce inequalities and reach gender equality. This is crucial to fostering tolerance and more peaceful societies.

- Reduced inequalities within and among countries (SDG 10). Social entrepreneurship supports efforts on social and cultural goals such as poverty and hunger to be erased, promote health, education and social protection for individuals in developing countries.

- Climate action (SDG 13). Social entrepreneurship establishes initiatives to tackle greenhouse gas emissions increase, acting against climate changes.

- Life below water (SDG 14). Social enterprise engages in initiatives to protect endangered species in the planet's main water. As the effect of SDG 13 , a lower degree of pollution due to dropping the level of greenhouse gas emissions would improve the oceans' acidification.

- Life on land (SDG 15). Social enterprise would focus on efforts towards protecting endangered animal species on land. Therefore, biodiversity can be persevered.

According to Figure 5 and 6, both the Fashion industry and Servitization clusters of application affect SDG 12 Responsible consumption and production. The fashion industry should bring to the market innovation and design solutions that direct consumption patterns towards a more sustainable course. Reducing wastes and more responsible buying of sustainable options would decrease environmental impacts and improving wellbeing. Likewise, Servitization changes the traditional customer consumption patterns, offering a ProductService System. The value of a PSS is a combination of product and service. Products are sold as functions: moving from owning a product to consume the service associated with it instead. Therefore, Servitization potentially leads to more sustainable and efficient use of natural resources. Less amount of waste will be generated.

As a consequence of the above, the Fashion industry and the Servitization affect:

- Climate action (SDG 13). A drop in the new product demand impacts the extraction of new materials and greenhouse gas emissions.
- Life below water (SDG 14). A lower degree of pollution due to the dropping level of greenhouse gas emissions would improve the ocean's acidification. Consequently, the marine environment would be threatened to a smaller extent by climate change.

- Life on land (SDG 15). A decline in new material extraction would preserve biodiversity, and forests would be managed more sustainably, preventing land degradation.

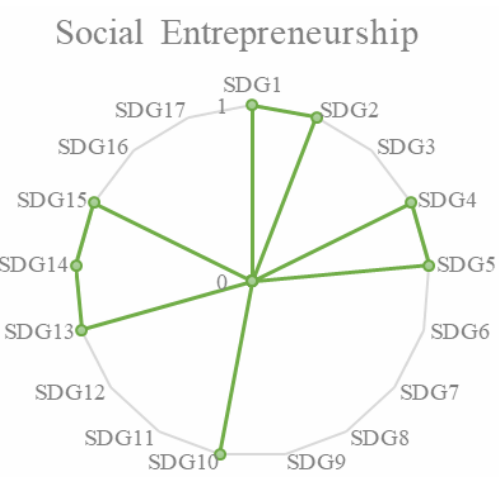

Figure 4. Social Entrepreneurship cluster of application effect on SDGs.

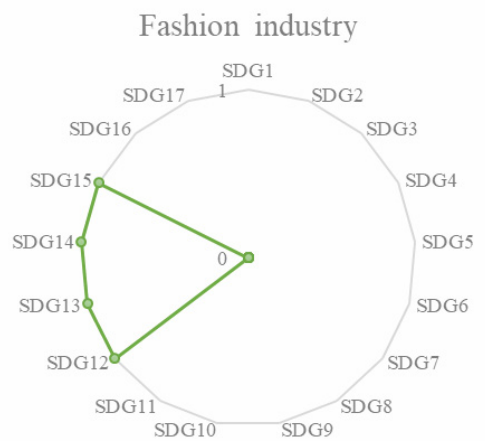

Figure 5. Fashion industry cluster of application effect on SDGs

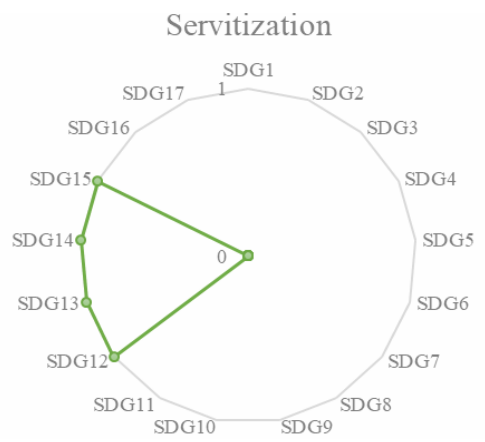

Figure 6. Servitization cluster of application effect on SDGs

Figure 7 shows the effect of the Construction project cluster of application on the SDGs.

In details:

- Industry, innovation and infrastructure (SDG 9). The goal is to stimulate investments towards building more resilient infrastructure. Social development is heavily dependent on it.

- Sustainable cities and communities (SDG 11). Unsustainable development of cities would lead to poorly planned urbanization. Cities should be designed and built to reduce urban traffic, leading to lower greenhouse gas emissions. 
- Climate action (SDG 13), as a side effect of SDG 11. The drop in greenhouse gas emissions will positively contribute to tackling climate change.

- Life below water (SDG 14). A lower degree of pollution due to the decreased greenhouse gas emissions would improve the ocean's acidification.

- Life on land (SDG 15). More sustainable development of cities would preserve biodiversity, sustainably manage forests, reversing land degra-dation and biodiversity loss.

According to Figure 8 and 9, both the Sharing economy and Sustainable production clusters of appli-cation affect SDG 12 - Responsible consumption and production. The sharing economy encourages resource distribution among a network. Therefore, this network's consumption patterns change from acquiring new resources to benefit from existing unused capacity within the network.

The circular economy concept prevails in the sustainable production cluster, driving a change in the tradi-tional production patterns. A company's production system needs to be designed as a closed-loop system that creates new value from waste, namely reusing existing materials.

SDG 12 affects Climate action (SDG 13), Life below water (SDG 14) and Life on land (SDG 15) in the same way, as for the fashion industry and Servitization cluster of applications.

Figure 10 shows the impact of the Renewable energy industry SBM cluster of application on the SDGs. In details:

- Affordable and clean energy (SDG 7). Technological advancement may facilitate the transition to cleaner energy. Therefore, renewable energy will be more accessible.

- Sustainable cities and communities (SDG 11). The extensive use of renewable energy technologies in an increased number of cities may boost integrated policies and action plans to ease climate change consequences.

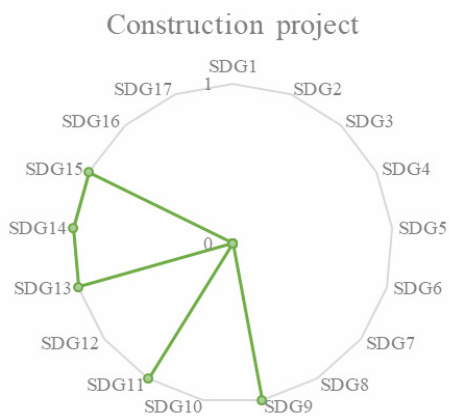

Figure 7. Construction project cluster of application effect on the SDGs

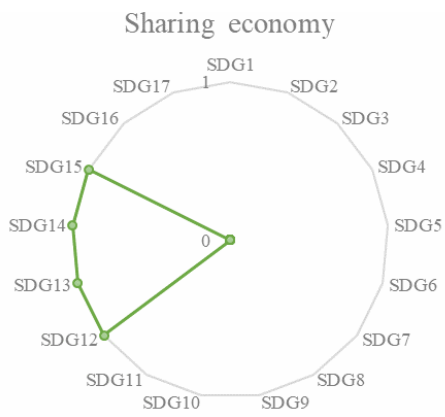

Figure 8. Sharing economy cluester of application effect on the SDGs

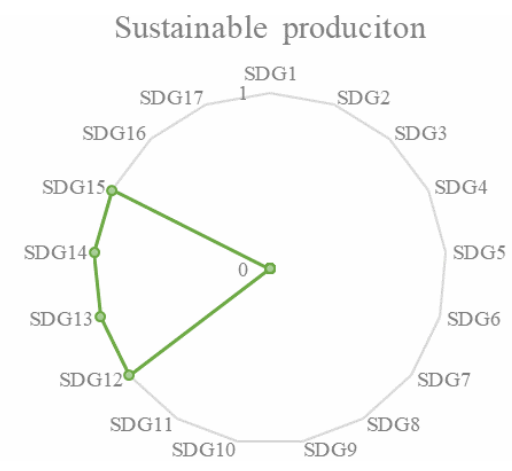

Figure 9. Sustainbale production cluster of application effect on the SDGs.

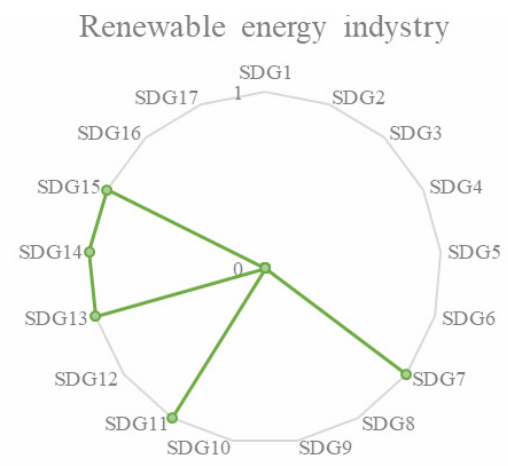

Figure 10. Renewable energy industry cluster of application effect on the SDGs

As a consequence of the impact on SDG 7 and SDG11, the following SDG are affected:

- Climate action (SDG 13). The greenhouse gas emissions would be reduced thanks to the increased use of renewable energy technology.

- Life below water (SDG 14). Less pollution due to less greenhouse gas emissions would improve the ocean's acidification. Consequently, the marine environment would be less threatened by climate change.

- Life on land (SDG 15). Urgent action is needed to reduce land degradation and the worrying loss of biodiversity caused by climate change effects.

- Renewable energy substitutes traditional energy systems to decrease greenhouse gas emissions.

Figure 11 shows the impact of the Digitalization SBM cluster of application on the SDGs. In details:

- Quality education (SDG 4). The digital transformation may facilitate access to education for all and even in an affordable way, through elearning.

- Industry, innovation and infrastructure (SDG 9). Digitalization promotes upgrading technological capabilities within the industry, encouraging innovation.

- Responsible consumption and production (SDG 12). The technological advancement brought by the digital transformation facilitates more sustainable consumption and production patterns, e.g. Internet of Things enables products as a service.

SDG 12 affects Climate action (SDG 13), Life below water (SDG 14) and Life on land (SDG 15) in the same way as for the Fashion industry, Servitization, Sharing economy and Sustainable production clusters of application. 
Figure 12 shows the impact of the Urban mobility SBM cluster of application on the SDGs. In details:

- Industry, innovation and infrastructure (SDG 9). The focus should be on improving information and communication technologies to support mobility services. Therefore, the goal is to promote technological innovation for urban mobility towards cities' smart support.

- Sustainable cities and communities (SDG 11). Rapid urbanization is critically affecting air pollution due to inadequate urban infrastructures and public services. The challenge for urban mobility concerns creating an acceptable quality of life for citizens. This can be achieved by developing a more sustainable and functional transportation network in energy consumption and pollution.

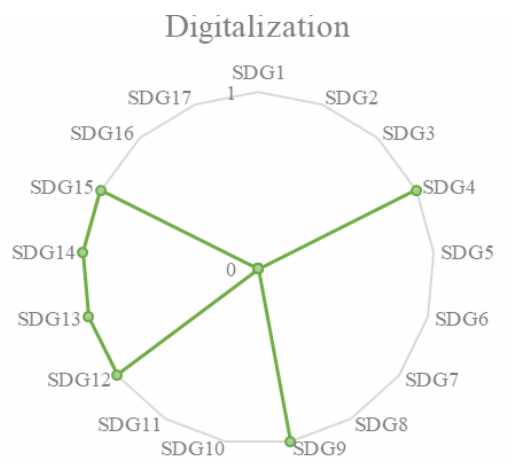

Figure 11. Digitalization cluster of application effect on the SDGs

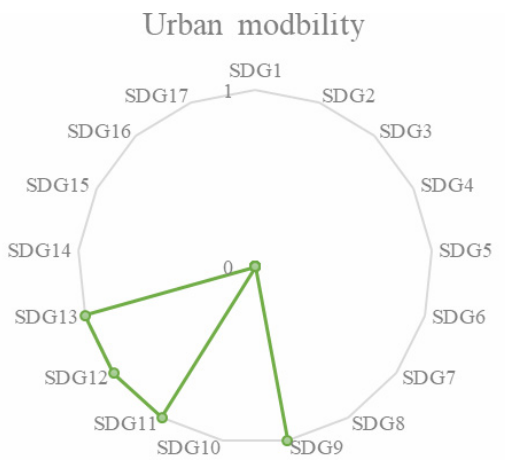

Figure 12. Urban modbility cluster of application effect on the SDGs

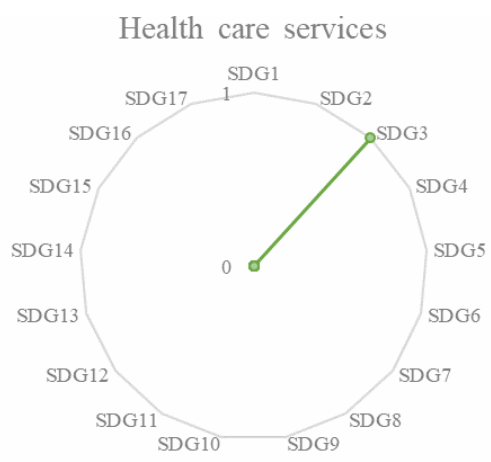

Figure 13. Health care services cluster of application effect on the SDGs

- Responsible consumption and production (SDG 12). The other challenge for urban mobility is shifting the current customer consumption patterns towards a more sustainable course. For instance, transportation services should be available for citizens as a possible choice over owning a means of transport.

- Climate action (SDG 13). Greenhouse gas emissions could be assumed to decrease, providing sustainable transportation services.

Figure 13 shows the impact of the Health care services SBM cluster of application on the SDGs. In details:

- Good health and well-being (SDG 3). Information technology would contribute to pursuing the goal of providing universal healthcare services access.

\section{CONSLUSION}

This paper presents the outcome of an extensive literature review based on a semantic approach that highlights the internal enablers and the most common application clusters for the SBM. The clusters are further analysed to determine their impacts on the SDGs.

SBM's applications have sustainable value propositions as primary source of a company's competitive advantage. The value propositions in SBM allow for social and environmental benefits creation. This is supported by a sustainability-oriented business strategy included in the SBM. The internal enablers presented in the results facilitate integrating sustainability issues into business strategy. The strategic agenda in organizations will be formulated to include sustainability-oriented goals, creating an internal commitment sustainability.

The internal enablers must be considered a prerequisite to encapsulate sustainability initiatives in a BM. This in turn, will generate a sound impact on SDGs.

The most common application clusters discussed within SBM's domain are presented in the results. The clusters of applications are mapped over the SDGs to highlight the sustainability impact of SBM. Analysing the map, it is possible to observe a sound impact on SDG 12. Most of the clusters of applications identified contribute to promoting production and consumption patterns towards a more sustainable course. From the customer's perspective, a SBM application contributes to transforming consumption behaviours. For instance, the sharing model has become popular over the traditional owing model with Servitization. A SBM application also contributes to innovate production patterns. Manufacturing companies should introduce production systems that fulfill sustainability goals. For instance, the traditional linear approaches may be redesign to create closed-loop systems which minimise the resources in input and the creation of waste.

The map presented may be seen as a tool that would support companies in assessing their sustainability impact during the transformation process towards SBM.

The mapping has considered only the general objective of the SDGs. As future work, additional research is needed to examine each cluster of application's effect on each target expected from each SDG. 


\section{REFERENCES}

[1] Digital, M., 2015, Industry 4.0 How to Navigate Digitization of the Manufacturing Sector.

[2] Pinheiro, P., Putnik, G. D., Dal, R., Fontana, B., and Romero, F., 2019, "Industry 4 . 0 and Industrial Revolutions: An Assessment Based on Complexity," FME Transcations, 47(4), pp. 831840.

[3] Frank, A. G., Delenogare, L. S., and Ayala, N. F., 2019, "Industry 4 . 0 Technologies: Implementation Patterns in Manufacturing Companies," Intern J. Prod. Econ., 210(September 2018), pp. 15-26.

[4] Khan, S. I., Ahmad, O. M., and Majava, J., 2021, "Industry 4 . 0 and Sustainable Development: A Systematic Mapping of Triple Bottom Line , Circular Economy and Sustainable Business Models Perspectives," J. Clean. Prod., 297, p. 126655.

[5] Tirabeni, L., Bernardi, P. D., and Forliano, C. 2019, "How Can Organisations and Business Models Lead to a More Sustainable Society: A Framework from a Systematic Review of the Industry 4 . 0," sustainability, pp. 1-23.

[6] Wu, J., Guo, S., Li, J., and Zeng, D., 2016, "Big Data Meet Green Challenges: Big Data Toward Green Applications,” IEEE Syst. J., 10(3), pp. 888900 .

[7] Oilveira, J. e S., Pereira, J. L., and Cacho, J., 2019, "Internet of Things Evolution: A European Perspective," FME Transcations, 47(4), pp. 739-748.

[8] Ingemarsdotter, E., Jamsin, E., Kortuem, G., and Balkenende, R., 2019, "Circular Strategies Enabled by the Internet of Things - A Framework and Analysis of Current Practice," sustainability.

[9] Rosa, P., Sassanelli, C., Urbinati, A., and Chiaroni, D., 2020, "Assessing Relations between Circular Economy and Industry 4.0: A Systematic Literature Review,” Int. J. Prod. Res., 58(6), pp. 1662-1687.

[10] Schaltegger, S., Hansen, E. G., and Lüdeke-freund, F., 2016, "Business Models for Sustainability: Origins , Present Research , and Future Avenues."

[11] Sneirson, J., 2014, “Green Is Good: Sustainability , Profitability, and a New Paradigm for Corporate Governance," IOWA LAW Rev., (March).

[12] Naomi, S., Bolis, I., Evans, S., Carvalho, M. M., 2017, "Transforming Sustainability Challenges into Competitive Advantage: Multiple Case Studies Kaleidoscope Converging into Sustainable Business Models," J. Clean. Prod., 167, pp. 723-738.

[13] Nosratabadi, S.et al., 2019, "Sustainable Business Models: A Review," pp. 1-30.

[14] Boons, F., and Lüdeke-freund, F., 2013, "Business Models for Sustainable Innovation: State-of-the-Art and Steps towards a Research Agenda," J. Clean. Prod., 45, pp. 9-19.

[15] Bocken, N. M. P., Short, S. W., Rana, P., and Evans, S., 2014, "A Literature and Practice Review to Develop Sustainable Business Model Archetypes," J. Clean. Prod., 65, pp. 42-56.
[16] Schaltegger, S., Hansen, E. G., and Lüdeke-freund, F., 2016, "Business Models for Sustainability: Origins , Present Research , and Future Avenues."

[17] Stubbs, W., 2008, "Conceptualizing a ' Sustainability Business Model” (2002), pp. 103-127.

[18] Tollin, K., and Vej, J., 2012, "Sustainability in Business: Understanding Meanings , Triggers and Enablers," 4488.

[19]Lüdeke-freund, F., 2010, “TOWARDS A CONCEPTUAL FRAMEWORK OF BUSINESS MODELS FOR SUSTAINABILITY," 49(0), pp. 128.

[20]Evans, S. et al., 2017, "Business Model Innovation for Sustainability: Towards a Uni Fi Ed Perspective for Creation of Sustainable Business Models," 608(April), pp. 597-608

[21]Zhao, W. et al. 2015, "A Heuristic Approach to Determine an Appropriate Number of Topics in Topic Modeling," BMC Bioinformatics, 16(Suppl 13), p. S8.

[22] Maier, D., Waldherr, A., Miltner, P., Wiedemann, G., Niekler, A., Keinert, A., Pfetsch, B., Heyer, G., Reber, U., Häussler, T., Adam, S., Maier, D., Waldherr, A., Miltner, P., Wiedemann, G., Niekler, A., and Keinert, A., 2018, "Applying LDA Topic Modeling in Communication Research: Toward a Valid and Reliable Methodology Applying LDA Topic Modeling in Communication Research:," Commun. Methods Meas., 12(2-3), pp. 93-118.

[23]Blei, D. M., Ng, A. Y., and Jordan, M. I., 2003, "Latent Dirichlet Allocation," 3, pp. 993-1022.

[24] Mimno, D., Wallach, H. M., Talley, E., Leenders, M., 2011, "Optimizing Semantic Coherence in Topic Models,” (2), pp. 262-272.

[25] Knutas, A., Hajikhani, A., Salminen, J., Ikonen, J., and Porras, J., 2015, "Cloud-Based Bibliometric Analysis Service for Systematic Mapping Studies," pp. 184-191.

[26] Asmussen, C. B., Møller, C., 2019, "Smart Literature Review: A Practical Topic Modelling Approach to Exploratory Literature Review," J. Big Data.

[27] Sievert, C., Shirley, K. E., and York, N., 2014, "LDAvis: A Method for Visualizing and Interpreting Topics," pp. 63-70.

[28] Chuang, J., Manning, C. D., and Heer, J., 2012, "Termite: Visualization Techniques for Assessing Textual Topic Models Categories and Subject Descriptors," pp. 74-77.

\section{КЛАСИФИКАЦИЈА ОДРЖИВИХ ПОСЛОВНИХ МОДЕЛА: ПРЕГЛЕД ЛИТЕРАТУРЕ И ПРЕСЛИКАВАЊЕ ЊИХОВОГ УТИЦАЈА НА ЦИЉЕВЕ ОДРЖИВОГ РАЗВОЈА}

\section{Е. Бофа, А. Мафеи}

Одрживи пословни модели (ОПМ) вићени су као погодно средство за организације да пренесу 
одрживост. ОПМ захтева да се пословна стратегија компаније обликује око циљева одрживости. Ови циљеви се могу интегрисати у пословну стратегију стварањем унутрашње усвојених обавеза усмерених на одрживост. Услови и инструменти који омогућавају ове циљеве играју кључну улогу у овом процесу интеграције.

Агенда Уједињених нација до 2030. године поставља јасне циљеве одрживог развоја, односно Циљеве Одрживог Развоја (ЦОР). Фирме се охрабрују да осмисле ОПМ за испуњење ових циљева. Ипак, недостаје опсежна истрага о утицају примена ОПМ -а на циљеве одрживог развоја.

Овај рад је заснован на семантичкој анализи релевантне литературе. Резултати показују унутрашње услове и инструменте који подржавају процес интеграције одрживости у стратегију организације. Поред тога, основни процес класификације наглашава групе апликација за СБМ. Они се, пак, пресликавају на циљеве одрживог развоја како би показали утицај сваке групе апликација на сваки циљ одрживог развоја.

\section{APPENDIX 1 - Topic Label And Description}

\begin{tabular}{|c|c|c|}
\hline Topic & Topic Label & Topic Description \\
\hline 1 & Framework design & Design framework for sustainability management \\
\hline 2 & Noise & \\
\hline 3 & SBM & BM includes sustainability dimension to maintain competitive advantage in the market \\
\hline 4 & Sustainability management & Development of framework to support the decision-making process \\
\hline 5 & Sustainability-oriented BM & Sustainability to be included in BM company's strategy for sustainability \\
\hline 6 & $\begin{array}{l}\text { Sustainable development } \\
\text { dimensions }\end{array}$ & Dimensions: social, environment and economy \\
\hline 7 & Health care service & Health care service: sustainable BM to support health care, health care information technology. \\
\hline 8 & Sustainable innovation & BM innovation for sustainability/sustainable development \\
\hline 9 & Servitization & Delivering functionality rather than ownership \\
\hline 10 & $\begin{array}{l}\text { Corporate social } \\
\text { responsibility }\end{array}$ & CSR and corporate integrated reporting \\
\hline 11 & Construction projects & $\begin{array}{l}\text { Projects should be aligned with sustainability dimension (direction toward sustainable } \\
\text { project); new BM to capture sustainable value }\end{array}$ \\
\hline 12 & Sustainability culture & Cultural changes in organisations to cope with sustainability strategy. \\
\hline 13 & Sustainable production & Waste reduction; Business model \\
\hline 14 & Digital transformation & Digital transformation driven by technological innovation. New BM required. \\
\hline 15 & Social entrepreneurship & $\begin{array}{l}\text { Social enterprise with the goal of positive environment and social (poverty, education, } \\
\text { gender) changes; BM to capture social value, translate social impact into financial } \\
\text { success; social entrepreneurship looks also at education. }\end{array}$ \\
\hline 16 & Urban mobility & Mobility: sustainable services for transportation in cities \\
\hline 17 & Renewable energy industry & $\begin{array}{l}\text { Transition to renewable energy: energy system, renewable energy technology, } \\
\text { governmental policy, policy implications }\end{array}$ \\
\hline 18 & Fashion industry & Fashion industry: towards sustainable consumption. New SBM required. "slow fashion". \\
\hline 19 & Sharing economy & Collaborative platform; SBM for collaborative platform \\
\hline 20 & Financial factors & Financial aspects of sustainable projects (capital investment, cost) \\
\hline 21 & Supply chain management & Supply chain in the food industry, agriculture and farming production. \\
\hline
\end{tabular}

\section{APPENDIX 2 - Sustainable Development Goals}

\begin{tabular}{|l|l|}
\hline SDG & \multicolumn{1}{|c|}{ Description } \\
\hline 1 & No poverty \\
\hline 2 & Zero Hunger \\
\hline 3 & Good health and well-being \\
\hline 4 & Quality education \\
\hline 5 & Gender equality \\
\hline 6 & Clean water and sanitation \\
\hline 7 & Affordable and clean energy \\
\hline 8 & Decent work and economic growth \\
\hline 9 & Industry, innovation and infrastructure \\
\hline 10 & Reduced Inequalities \\
\hline 11 & Sustainable cities and communities \\
\hline
\end{tabular}




\begin{tabular}{|l|l|}
\hline 12 & Responsible consumption and production \\
\hline 13 & Climate action \\
\hline 14 & Life below water \\
\hline 15 & Life on land \\
\hline 16 & Peace, justice and strong institutions \\
\hline 17 & Partnerships for the goals \\
\hline
\end{tabular}

